\title{
Analysis of Economic Regulations of National Electrical Systems
}

\author{
Yusuf Suryanto' \\ Ministry of National Development Planning/BAPPENAS
}

\begin{abstract}
The performance of the national electricity industry is inadequate. Improvements have so far ignored the highly centralized structure of the national electricity industry. Using the theory of industrial organization, comparative with developed countries, and considering the prevailing legal corridor, this paper recommends policy, in order to (i) create an un-centratious electricity system by establishing 5 electricity systems in Indonesia; (ii) continuing efforts to utilize shared networks Transmission (and distribution), and (iii) establishing the Electricity Industry Regulators. The main recommendation is to break-down the current PLN into 5 new electricity companies.
\end{abstract}

Keywords: Regulation, Electricity Policy, Energy 


\section{Analisis Regulasi Ekonomi Sistem Ketenagalistrikan Nasional}

\section{Pendahuluan}

Kinerja (performance) sistem ketenagalistrikan nasional belum memadai, terlihat dari rendahnya kapasitas pembangkit listrik, rasio elektrifikasi, dan konsumsi listrik per kapita. Upaya pemerintah memperbaiki kinerja ini, misalnya melalui Program Percepatan Pembangkit $10 \mathrm{GW}$ dan Program 35.000 MW belum menunjukkan hasil yang signifikan. Menurut Clobal Competitiveness Report, layanan suplai tenaga listrik Indonesia (86) masih jauh di bawah Thailand (56), dan hanya satu tingkat di atas Vietnam (87).

Dari sisi regulasi, beberapa kebijakan juga telah dikeluarkan untuk memperbaiki kinerja sistem ketenagalistrikan tersebut, namun kinerja pembangunan ketenagalistrikan belum juga membaik. Diyakini masih ada kendala mendasar yang belum disentuh oleh pemerintah yaitu kondisi struktur industri yang masih sentralistik terintegrasi dalam satu sistem ketenagalistrikan yang sangat luas.

Teori organisasi industri (industrial organization) berpandangan bahwa kinerja (performance) suatu industri dipengaruhi oleh perilaku (conduct) para agen (produsen dan konsumen) dalam struktur (structure) industri yang melingkupinya. Struktur industri terdiri dari tiga komponen utama yaitu konsentrasi pasar, diferensiasi produk, dan hambatan untuk masuk (barrier to entry). Paradigma struktur-perilaku-kinerja (SPK) tersebut juga mempengaruhi (dan dipengaruhi) pemerintah (government). Dua elemen kebijakan yang dilakukan oleh pemerintah terkait hal ini adalah anti monopoli (antitrust) dan regulasi (regulation). Regulasi ekonomi (economic regulation) menyatakan bahwa sumber daya pokok pemerintah adalah kemampuannya untuk memaksa (membatasi pilihan yang dapat dilakukan oleh agen-agen ekonomi) dalam hal harga, jumlah barang, dan entry and exit.

Untuk memperbaiki kinerja industri ketenagalistrikan nasional perlu upaya untuk memperbaiki struktur industrinya. Industri ketenagalistrikan adalah industri yang diregulasi (regulated) sehingga efisiensi alokasi dan produksi ditentukan oleh kekuatan pasar (market forces) dan juga proses administrasi (administrative processes) oleh pemerintah.

Tulisan ini mengulas rumusan masalah sebagai berikut "Apa dan bagaimana struktur industri ketenagalistrikan yang efisien dalam kerangka analisis regulasi ekonomi agar mampu memberikan peningkatan pelayanan kepada seluruh masyarakat". Tulisan ini dimaksudkan untuk membantu perumusan kebijakan untuk mengembangkan sistem ketenagalistrikan yang lebih efisien, dengan mengajukan pendekatan merestrukturisasi industi ketenagalistrikan nasional yang sesuai dengan aturan/UU saat ini. Penelitian dilakukan melalui studi literatur, sedangkan analisis dilakukan juga dengan mempelajari sistem ketenagalistrikan di Amerika Serikat dan Jepang. 


\section{Kajian Pustaka}

\subsection{Sistem Ketenagalistrikan}

Sistem ketenagalistrikan terdiri dari sub-sistem pembangkitan, sub-sistem transmisi dan sub-sistem distribusi, dan penjualan tenaga listrik ke konsumen (end users). Sub-sistem pembangkitan listrik adalah proses produksi energi listrik baik memanfaatkan energi potensial air, turbin pembangkitan pada berbagai sumber energi seperti batubara, gas alam, angin dan solar energy. Ciri utama dari energi listrik yang dibangkitkan adalah tidak dapat simpan (non-storability) sehingga kebutuhan (konsumsi) listrik dan pembangkitan energi listrik harus diusahakan selalu sinkron.

Gambar 1. Hubungan Pembangkit, Transmisi, dan Distribusi

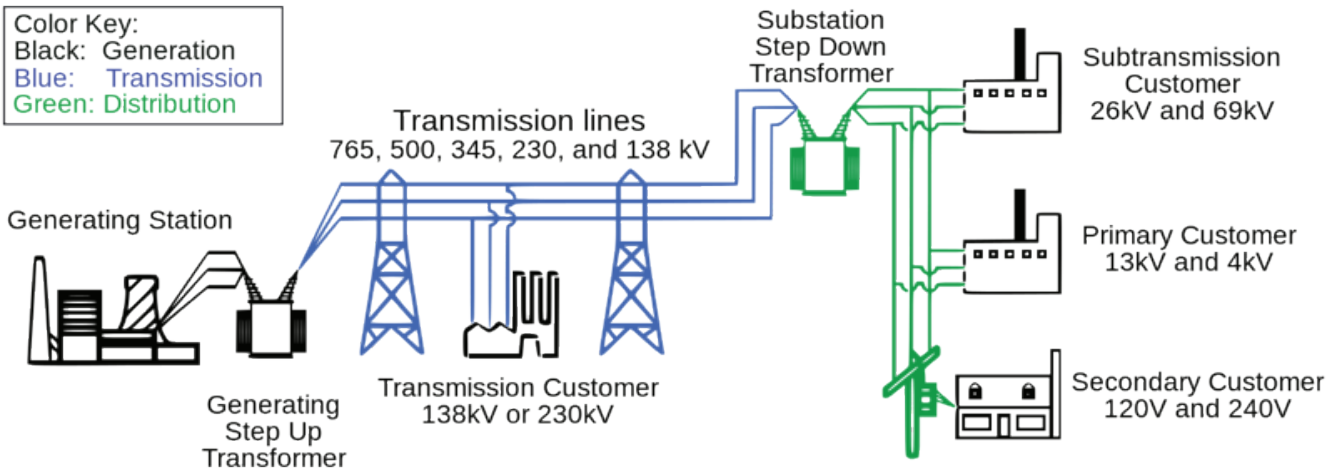

Sumber: http://en.wikipedia.org/wiki/File:Electricity_grid_simple-_North_America.svg

Sub-sistem transmisi energi listrik melibatkan kabel-kabel (wires), trafo (transformers), dan fasilitas gardu (substations) yang mampu memindahkan energi listrik bertegangan tinggi yang stabil dan sinkron ke berbagai wilayah. Subsistem transmisi menjalankan fitur penting yaitu pengaturan (penjadwalan dan penyaluran) aliran berbagai jenis pembangkit yang tersebar di berbagai wilayah, menyeimbangkan (balancing) suplai dengan permintaan yang berfluktuasi, mengatur (managing) kegagalan berbagai peralatan, keterbatasanjaringan (network constraints) dan hubungan dengan jaringan transmisi lainnya (interkoneksi). Dalam perkembangannya, sistem transmisi juga berfungsi sebagai pasar (market) untuk kompetisi yang terbuka dan adil dari penjualan wholesale energi listrik. Dengan demikian sistem transmisi menjadi tulang punggung (backbone) bagi keseluruhan sistem ketenagalistrikan. Selanjutnya, penjualan listrik ke berbagai konsumen dilakukan oleh distributor dan/atau retailer melalui jaringan dan trafo distribusi bertegangan rendah sebagai bagian dari sub-sistem distribusi.

\subsection{Regulasi dan Ekonomi Ketenagalistrikan}

Berbeda dibanding beberapa dekade yang lalu, sistem ketenagalistrikan modern memisahkan (unbundle) sub-sistem pembangkitan dari sub-sistem transmisi dan sub-sistem distribusi. Joscow (1997) menyatakan bahwa pemisahan sektor pembangkitan adalah karena pembangkitan tenaga listrik tidak lagi natural monopoly sebagai akibat dari perkembangan teknologi. Dengan demikian, tingkat kompetisi dari masing-masing proses menjadi berbeda-beda.

Pada sub-sistem pembangkitan tenaga listrik yang tidak lagi natural monopoly terjadi kompetisi secara penuh. Harga energi listrik di sisi pembangkitan tidak lagi 
diatur oleh pemerintah tetapi lebih ke arah persaingan usaha atau kompetisi. Sedangkan sistem transmisi dan distribusi masih diregulasi (regulated) karena masih dianggap bersifat monopoli alami (natural monopoly). Harga listrik di sistem transmisi dan distribusi ditentukan oleh institusi yang independen (regulator).

Konsep unbundling juga mensyaratkan sistem transmisi bersifat terbuka (shared infrastructure) untuk mendorong kompetisi di sisi pembangkitan. Adanya kesetaraan akses akan sistem transmisi mempercepat produksi listrik sampai ke konsumen, yang pada akhirnya meningkatkan jumlah kapasitas pembangkit tenaga listrik.

Jenis struktur pasar (market structure) dari sebuah sistem ketenagalistrikan dapat ditentukan dari pihak yang memiliki pilihan atau untuk dapat memilih. Berdasarkan hal tersebut dapat di bagi empat jenis struktur yaitu (1) monopoly; (2) single buyer; (3) wholesale competition; dan (4) retail competition. Tipe yang pertama adalah bentuk monopoli secara keselurahan (vertically integrated utility) dimana tidak ada kompetisi sama sekali dan pemerintah mengendalikan secara penuh penyediaan tenaga listrik (biasanya melalui badan usaha milik negara).

Pada jenis yang kedua kompetisi mulai dibuka namun hanya di sistem pembangkitan sehingga hanya satu vertically integrated public utility yang memiliki pilihan untuk membeli energi listrik dari berbagai suppliers (monopsoni). Evolusi selanjutnya adalah jenis yang ketiga dimana sistem transmisi dipisahkan (independent) sehingga distributorlah yang memiliki pilihan untuk menentukan supplier energi baik melalui energy market (energy power pool) maupun bilateral contract. Jenis yang terakhir adalah level kompetisi paling tinggi dimana konsumen dapat memilih supplier energi yang sesuai.

Gambar 2. Alternatif Struktur Pasar Ketenagalistrikan

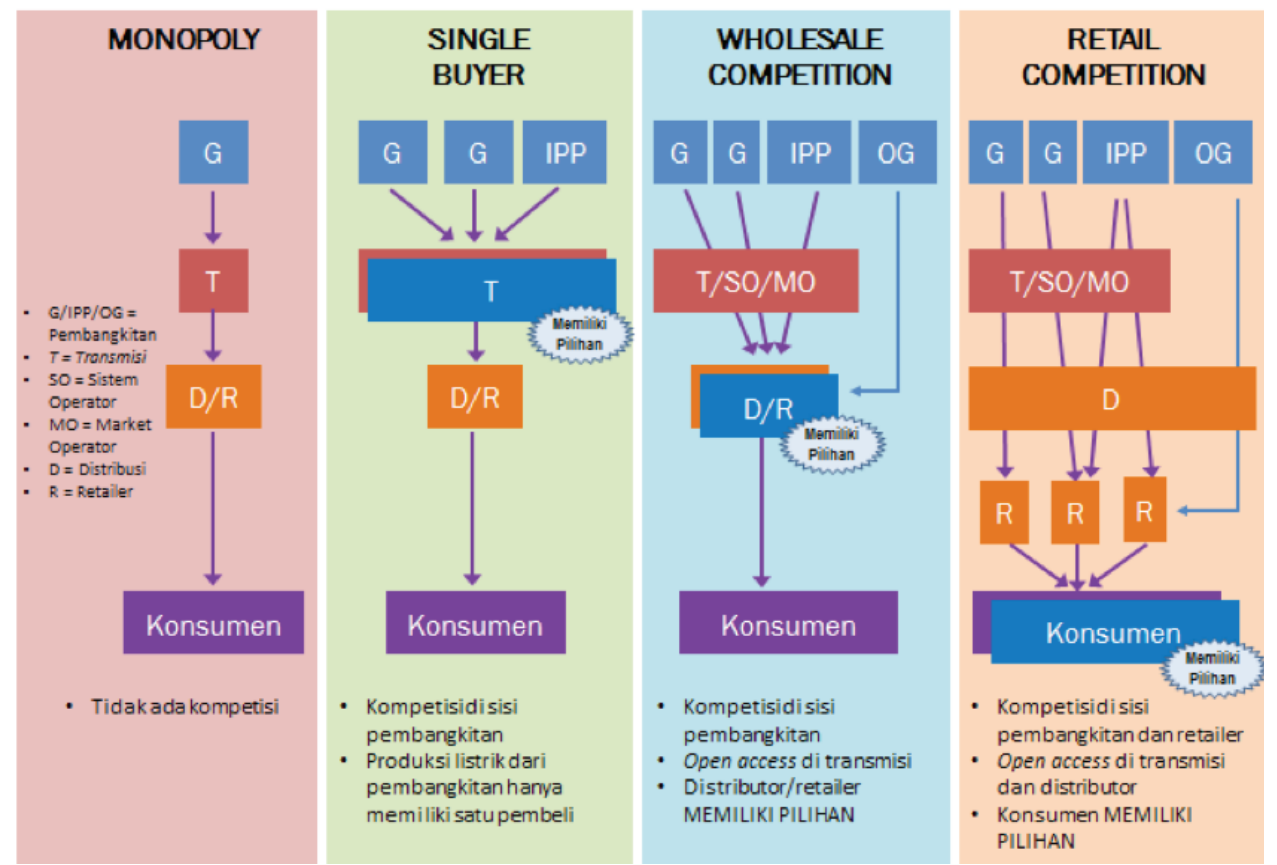

Sumber: diolah dari berbagai sumber 
Paradigma struktur-perilaku-kinerja dalam suatu industri mengandung pengertian bahwa ada hubungan atau keterkaitan sebab akibat dari ketiga unsur tersebut (Gambar 3). Struktur suatu industri menentukan perilaku (conduct) dari pelaku (badan usaha) dalam industri dimaksud yang kemudian akan menentukan kinerja (performance) dari industri. Walaupun demikian, hubungan ketiganya tidak searah namun ada keterkaitan timbal balik dimana perilaku badan usaha dapat mempengaruhi struktur industri.

Selain itu, ada pengaruh kebijakan pemerintah (government policy) yang mempengaruhi struktur dan perilaku dari suatu industri. Proses timbal balik juga terjadi dimana perilaku dari agen-agen ekonomi mempengaruhi kebijakan pemerintah.

Gambar 3. Model Struktur-Perilaku-Kinerja (SPK)

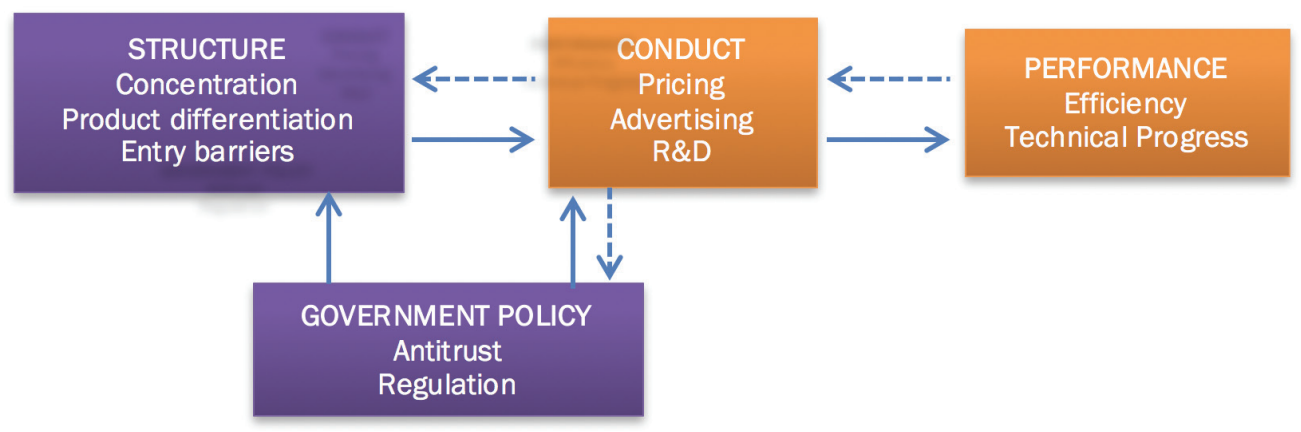

Sumber: Viscusi W.K., 2005

Terkait dengan konsentrasi pasar, ukuran dilakukan dengan melihat pangsa pasar (market share) dari masing-masing badan usaha yang terlibat dari suatu industry, baik product market maupun geographic market. Relevansi suatu produk dilihat dari elastisitasnya apakah produk tersebut bersifat substitute atau complement.

\subsection{Sistem Ketenagalistrikan Dunia (Amerika Serikat dan Jepang)}

Amerika Serikat mulai merestrukturisasi sistem ketenagalistrikannya sekitar 4 dekade lalu melalui Public Utility Regulatory Policy Act (PURPA, 1978) dimana Federal Energy Regulatory Comission (FERC) menciptakan kategori baru untuk produsen tenaga listrik yang disebut qualifying facilities (QF) dan independent power producer (IPP). Restrukturisasi dilanjutkan pada tahun 1992 melalui Energy Policy Act (EPA) dimana harga energi listrik di sisi pembangkitan menggunakan harga pasar (market pricing) atau tidak lagi menggunakan cost-based pricing.

Selanjutnya, FERC melalui Order 888/889 (1996) dan Order 2000 (1999) melakukan restrukturisasi dengan mengamanatkan bahwa jaringan transmisi harus dibuka ke semua pihak dengan pemisahan (unbundling) tariff untuk pembangkitan, transmisi, dan ancillary services. Selain itu diamanatkan pembentukan independent sistem operator (ISO) atau regional transmission organization (RTO) sebagai pelaksana sistem transmisi yang independen. Dengan demikian, konsumen tidak lagi tergantung pada pada supplier unggal namun memiliki kebebasan untuk memilih dari berbagai supplier. Peran ISO menjadi sangat penting selain menjaga keandalan sistem juga sebagai tempat bertemunya penjual dan pembeli (market place). Pada tahap awal, konsumen yang memiliki hak untuk memilih supplier energi terbatas hanya untuk distributor namun sekarang 
telah berkembang dengan memasukkan konsumen tertentu sebagai konsumen yang berhak memilih (tingkar retailer).

Hasil dari proses penyempurnaan regulasi tersebut adalah terbentuknya tujuh RTO/ISO yaitu PJM interconnection, Southwest Power Pool (SPP) dan Electric Reliability Council of Texas (ERCOT), Californa ISO, Midwest ISO, New York ISO, dan New England ISO. Di sisi distribusi terdapat sekitar 3.170 Public Utilities yang berada di bawah pengawasan regulator di tingkat negara bagian (state level).

Jepang sampai tahun 1995 menganut sistem single buyer, dimana sepuluh perusahaan penyedia listrik regional (electric power company/EPCO) yang dibentuk dari perusahaan distribusi menyediakan listrik ke seluruh penduduk di wilayah masing-masing dengan tarifyang diatur pemerintah. Untuk itu, perusahaan tersebut diberikan hak monopoli dan monopsoni. Sembilan perusahaan yaitu Hokkaido EPCO, Tohoku EPCO, Tokyo EPCO (TEPCO), Hokuriku EPCO, Chubu EPCO, Kansai EPCO (KEPCO), Chugoku EPCO, Shikoku EPCO, dan Kyushu EPCO dibentuk pada tahun 1951, sementara Okinawa EPCO dibentuk tahun 1972.

Restrukturisasi sistem ketenagalistrikan di Jepang kembali dilakukan pada tahun 2002 dimana extra-high voltage customers dengan konsumsi di atas $20 \mathrm{kV}$ diliberalisasi. Hal ini berarti struktur pasar telah berubah menjadi retail competition yaitu konsumen (dalam kategori tertentu) diberikan hak untuk memilih suplier yang sesuai. Kesempatan bagi pendatang baru (new entries) di sisi retail mulai dibuka, namun monopoli (oleh EPCO) tetap dipertahankan, namun jaringan transmisi dibuka untuk seluruh pengguna (open access). Pembukaan sisi retail terus dilakukan; sampai dengan saat ini yang diliberalisasi adalah (1) konsumen tegangan tinggi (6kV) dengan konsumsi $500 \mathrm{~kW}$ atau lebih dan (2) seluruh konsumen tegangan tinggi dengan konsumsi 50kW atau lebih.

Sebagai bagian dari restrukturisasi, dibentuk dua lembaga baru yaitu Electric Power Sistem Council of Japan (ESCJ) dan Japan Electric Power Exchange (JPEX). ESCJ dibentuk pada tahun 2004 untuk memastikan terjaganya prinsip keadilan dan transparansi di sisi transmisi dan distribusi yang masih dikuasai EPCO. Tugas dari ESJC itu sendiri adalah memformulasikan aturan-aturan baku dan juga memonitor pasar serta menangani perselisihan yang mungkin timbul. Sedangkan JPEX dibentuk pada tahun 2003 yang dimaksudkan untuk menjalankan pasar jual beli tenaga listrik wholesale.

Gambar 4. Struktur Ketenagalistrikan di Jepang

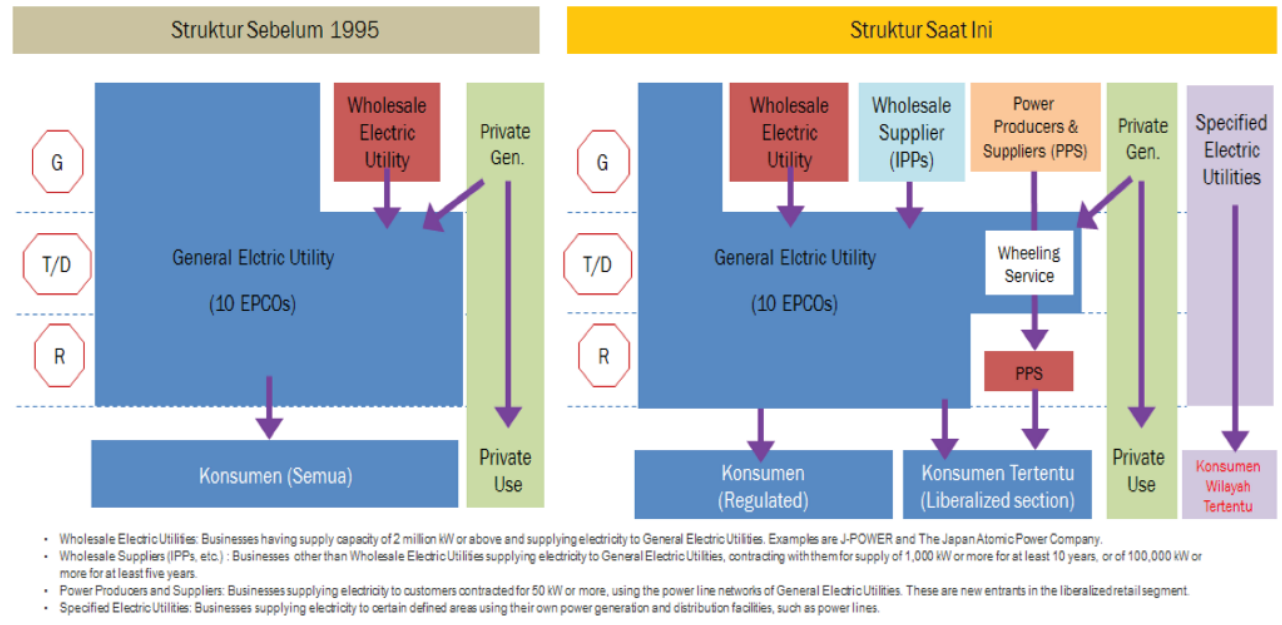




\section{Analisis Sistem Ketenagalistrikan Indonesia}

\subsection{Perkembangan Sistem Ketenagalistrikan dan Regulasi}

Pelayanan ketenagalistrikan di Indonesia sudah dimulai sejak jaman kolonial Belanda. Pada tahun 1965 pemerintah membentuk perusahaan umum milik negara Perusahaan Listrik Negara (Perum PLN), sebuah badan usaha yang memiliki tugas mengelola ketenagalistrikan nasional. Selanjutnya peraturan pemerintah (PP) Nomor 17 tahun 1972 mengubah Perum PLN menjadi PT. PLN, sekaligus melimpahkan kewenangan pembangunan ketenagalistrikan pada PT. PLN sebagai Pemegang Kuasa Usaha Ketenagalistrikan (PKUK) untuk seluruh wilayah Indonesia.

Keputusan Presiden No. 37/1992 tentang Usaha Penyediaan Tenaga Listrik oleh Swasta telah membuka kesempatan bagi pihak swasta untuk berpartisipasi dalam penyedian tenaga listrik, terutama di sisi pembangkitan. Badan usaha Swasta dan Koperasi dimungkinkan untuk berperan dalam penyediaan tenaga listrik baik pada proyek-proyek yang ditentukan oleh Pemerintah maupun atas prakarsa sendiri. Peran serta badan usaha meliputi pembangunan pembangkit listrik dan transmisi sertajaringan distribusi dengan skema membangun, memiliki, dan mengoperasikan (build, own, operate/BOO). Beberapa ketentuan khusus lainnya dalam peraturan tersebut diantaranya adalah (a) harga jual tenaga listrik, harga sewa jaringan transmisi dan harga sewa jaringan distribusi dinyatakan dalam mata uang rupiah; (b) usaha penyediaan tenaga listrik oleh swasta hanya dapat dilaksanakan dengan pembiayaan tanpa jaminan Pemerintah; dan (c) Pemerintah memberikan fasilitas (insentif) berupa pembebasan bea masuk dan pajak atas impor barang modal. Dengan demikian Keppres dimaksud telah mengubah struktur industri ketenagalistrikan Indonesia dimana konsep pembangkit listrik swasta (independent power producer) diperkenalkan. Namun konsep tersebut tidak dapat berjalan dengan mulus akibat terjadinya krisis moneter pada akhir dekade 90-an.

Selanjutnya pada tahun 2002, pemerintah (bersama DPR) mengesahkan UU 21/2002 tentang Ketenagalistrikan. UU ini mencoba merestrukturisasi sistem ketenagalistrikan melalui pemisahan (unbundling) sub-sistem pembangkitan, transmisi, dan distribusi. Namun, UU ini pun akhirnya dibatalkan oleh Mahkamah Konstitusi karena dianggap melepas kewenangan Negara atas komoditas yang penting (tenaga listrik).

Pada tahun 2009 melalui UU 30/2009 pemerintah sekali lagi mencoba melakukan restrukturisasi sistem ketenagalistrikan. Fitur-fitur utama dari UU tersebut adalah: (a) dibukanya kesempatan badan usaha (swasta, koperasi maupun BUMD) untuk membangun pembangkit listrik, transmisi, distribusi, dan penjualan (retailer); (b) dibukanya kesempatan sebagai badan usaha terintegrasi ketenagalistrikan selain PT. PLN; (c) dimungkinkannya tarif regional yang ditetapkan oleh pemerintah daerah dengan persetujuan DPRD; dan (d) PT. PLN tidak lagi menjadi pemegang kuasa usaha ketenagalistrikan (PKUK). Skema sederhana struktur industri ketenagalistrikan sesuai dengan UU 30/2009 disajikan dalam Gambar 4. 
Struktur Sesuai UU 30/2009

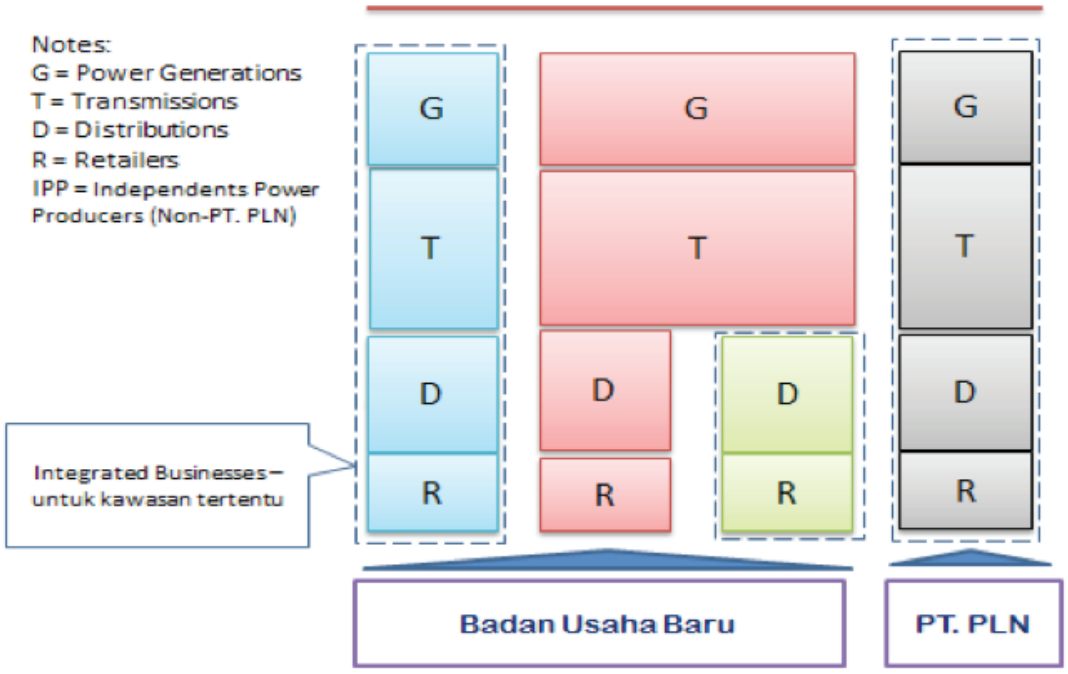

Dalam kenyataannya, restrukturusisasi sebagaimana harapan UU 30/2009 masih jalan di tempat. Peran PT. PLN masih sangat dominan bahkan tetap memonopoli penyediaan tenaga listrik untuk kepentingan umum di seluruh Indonesia. Struktur industri ketenagalistrikan di Indonesia yang sesungguhnya disajikan dalam Gambar 5.

Gambar 6. Struktur Ketenagalistrikan di Indonesia

\section{INDONESIA}
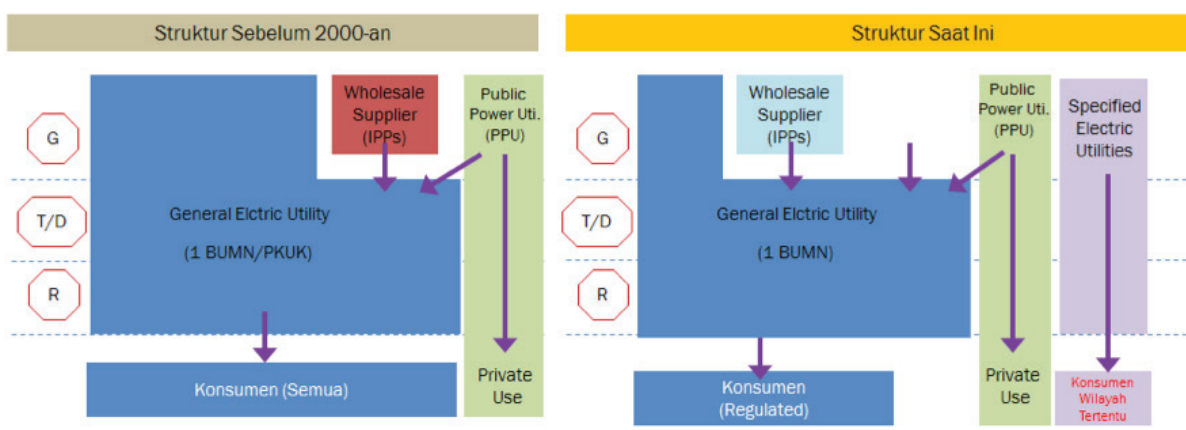

Pada akhir tahun 2016, UU 30/2009 kembali menghadapi tantangan dimana MK memutuskan bahwa pasal 10 ayat 2 UU dimaksud bertentangan dengan Undang-Undang Dasar (UUD) 1945, secara bersyarat tidak memiliki kekuatan hukum mengikat, apabila rumusan dalam Pasal 10 ayat 2 Undang-Undang ketenagalistrikan tersebut menjadi dibenarkannya praktik unbundling dalam usaha penyediaan tenaga listrik untuk kepentingan umum sedemikian rupa sehingga menghilangkan kontrol negara sesuai dengan prinsip dikuasai negara. Hal serupa berlaku untuk pasal 11 ayat $1 \cup U$ yang sama. 


\subsection{Pembahasan}

Terdapat beberapa perbedaan struktur industri ketenagalistrikan di Indonesia, Amerika Serikat, dan Jepang. Perbedaan tersebut dapat diringkas seperti pada Tabel 1.

Tabel 1. Perbandingan Industri Ketenagalistrikan

\begin{tabular}{|c|c|c|c|}
\hline & Amerika & Jepang & Indonesia \\
\hline $\begin{array}{l}\text { Geografis dan } \\
\text { Demografis }\end{array}$ & $\begin{array}{ll}\text { - } & \text { Satu kesatuan daratan } \\
\text { - } & 316,47 \text { juta penduduk } \\
\end{array}$ & $\begin{array}{ll}\text { - } & \text { Pegunungan \& Kepulauan } \\
\text { - } & 127,33 \text { juta penduduk }\end{array}$ & $\begin{array}{ll}\text { - } & \text { Kepulauan } \\
\text { - } & 242 \text { juta penduduk }\end{array}$ \\
\hline Performance & $\begin{array}{ll}\text { - } & \text { Handal dan Cukup } \\
\text { - } & \text { RE: } 100 \% \\
\text { - } & \text { Konsumsi per kapita: } 12.987 \\
& \text { kWh } \\
\text { - } & \text { Produksi listrik: } 4.109,84 \\
& \text { TWh }\end{array}$ & $\begin{array}{ll}- & \text { Handal dan Cukup } \\
\text { - } & \text { RE: } 100 \% \\
\text { - } & \text { Konsumsi per kapita: } 7.836 \\
& \text { kWh } \\
\text { - } & \text { Produksi listrik: } 4.070,52 \\
& \text { TWh } \\
\end{array}$ & $\begin{array}{ll}\text { - } & \text { Kurang dan tidak handal } \\
\text { - } & \text { RE: } 89 \% \\
\text { - } & \text { Konsumsi per kapita: } 792 \\
& \text { kWh } \\
\text { - } & \text { Produksi listrik: } 197,92 \\
& \text { TWh }\end{array}$ \\
\hline Struktur & $\begin{array}{l}\text { Unbundling Vertically and } \\
\text { geographically }\end{array}$ & $\begin{array}{l}\text { Unbundling Vertically and } \\
\text { geographically }\end{array}$ & $\begin{array}{l}\text { Vertically and geographically } \\
\text { Integrated }\end{array}$ \\
\hline Pembangkitan & Kompetisi & Kompetisi & Kompetisi Terbatas (IPP) \\
\hline Transmisi & 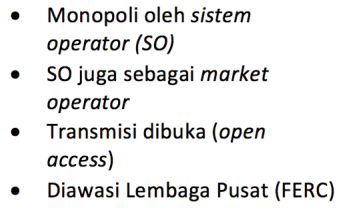 & $\begin{array}{l}\text { Monopoli oleh regional } \\
\text { company (10 EPCOs) } \\
\text { - Transmisi dibuka (power } \\
\text { wheeling) } \\
\text { - Diawasi Lembaga Pusat (ESCJ) }\end{array}$ & $\begin{array}{l}\text { - Monopoli oleh satu BUMN } \\
\text { (PT. PLN) } \\
\text { - Transmisi dibuka (open } \\
\text { access) belum implementable. } \\
\text { - Lembaga pengawas } \\
\text { (regulator) tidak ada. }\end{array}$ \\
\hline Distribusi & $\begin{array}{l}\text { Monopoli oleh distributor ( } 3000- \\
\text { an perusahaan) }\end{array}$ & $\begin{array}{l}\text { Monopoli oleh distributor (10 } \\
\text { EPCOs) }\end{array}$ & $\begin{array}{l}\text { Monopoli oleh satu BUMN (PT. } \\
\text { PLN) }\end{array}$ \\
\hline Retailer & Di liberalisasi (customer choices) & $\begin{array}{l}\text { Di liberalisasi untuk konsumen } \\
\text { tertentu }\end{array}$ & Non-kompetisi \\
\hline
\end{tabular}

Untuk Indonesia, implikasi dari sistem saat ini adalah kinerja sistem ketenagalistrikan nasional belum menggembirakan. Hal tersebut dapat dilihat dari indikator rasio elektrifikasi yang baru mencapai 80 persen di tahun 2013, atau sekitar 50 juta penduduk belum menerima layanan ketenagalistrikan. Dibandingkan Amerika Serikat dan Jepang, kondisi tersebut amatlah memprihatinkan; demikian pula dibandingkan negara tetangga seperti Malaysia dan Thailand, kondisi Indonesia lebih buruk. Menurut Clobal Competitiveness Report 2015, keterbatasan layanan infrastruktur adalah problem utama Indonesia setelah korupsi dan inefisiensi birokrasi. Kualitas suplai tenaga listrik Indonesia hanya menduduki peringkat 86 dari 140 negara, di bawah Thailand (56) dan hanya satu peringkat di atas Vietnam (87).

Penyebab rendahnya kinerja industri ketenagalistrikan nasional dapat dijelaskan dari kerangka struktur-perilaku-kinerja (SPK). Kinerja yang rendah disebabkan perilaku dan struktur industri yang tidak mendukung terciptanya kinerja yang baik. Mengingat industri ketenagalistrikan sangat heavily regulated, maka hal tersebut ditentukan pula oleh kebijakan pemerintah.

Struktur industri ketenagalistrikan diwarnai oleh terbatasnya jumlah penyedia barang/jasa (seller) yaitu hanya PT PLN yang menguasai hampir seluruh industri dari mulai sistem pembangkitan sampai dengan penjualan (vertically integrated). Untuk sub-sistem pembangkitan, pasar PT PLN berkisar pada angka 70 persen dimana pada tahun 2015 produksi listrik dari PT PLN mencapai 176,5 TWh sedangkan IPP hanya sebesar 57,5 TWh. Pada tingkatan regional, konsentrasi pasar dari PT PLN bahkan mencapai 100 persen. Peran badan usaha lain masih terbatas di sebagian kecil regional. Badan usaha yang berfungsi sebagai vertically integrated utility 
hanya ada di Batam, Tarakan, dan beberapa kawasan industri lainnya. Bahkan UU 30/2009 mengamanatkan bahwa PT PLN sebagai the last resort untuk wilayah yang belum ekonomis.

Selain itu, entry barriers juga masih tinggi seperti belum adanya kejelasan tentang keterbukaan akses pada sistem transmisi (open access/shared infrastructure) dan tingginya cost of capital yang harus ditanggung oleh badan usaha untuk memulai usaha. Dengan demikian, struktur industri di pembangkitan belum memperlihatkan kompetisi yang cukup.

Perilaku (conduct) merujuk pada keputusan yang diambil oleh badan usaha berkaitan dengan harga, kuantitas produksi, advertising dan juga R\&D. Secara umum perilaku ini merujuk pada dua kondisi umum yaitu kompetisi dan kolusi. Industri ketenagalistrikan menunjukkan tidak adanya kompetisi yang signifikan di semua tingkatan.

Hal-hal tersebut di atas merupakan hasil dari aturan yang disusun pemerintah. Pelimpahan wewenang sebagai pemegang kuasa usaha ketenagalistrikan (PKUK) di masa lampau membatasi jumlah pelaku dan penentuan harga (pricing policy) menentukan tingkat kompetisi yang rendah karena badan usaha beroperasi dalam keadaan merugi. Dengan demikian, industri ketenagalistrikan perlu disempurnakan mulai dari aturan-aturan yang ada agar mampu mendorong struktur dan perilaku usaha yang lebih kompetitif. Aturan harus mampu mengundang pelaku industri berperan serta dan mengurangi hambatan-hambatan untuk masuk. Aturan juga perlu disusun agar perilaku usaha terkait pricing dapat mendorong berkembangnya industri secara keseluruhan.

Upaya pemerintah yang dapat ditempuh terkait dengan kondisi di atas adalah (1) memperbaiki struktur industri ketenagalistrikan nasional dan/atau (2) memperbaiki kebijakan harga baik di berbagai tingkatan sub-sistem industri.

Butir (2) sudah dilaksanakan oleh pemerintah melalui penetapan harga baik harga beli tenaga listrik di pembangkitan maupun harga beli tenaga listrik di tingkat konsumen. Subsidi yang selama ini dianggap masalah juga telah mulai diperbaiki menuju ke arah subsidi langsung tepat sasaran. Permen ESDM 31/2004 mengatur tariff adjustment harga listrik yang semula dipatok tetap dalam jangka waktu tertentu menjadi fluktuatif sesuai dengan beberapa indikator yaitu nilai tukar, harga minyak mentah (bahan bakar) dan inflasi. Proses jual beli dan harga beli tenaga listrik antara pengembang dengan PT PLN juga telah diupayakan untuk mendorong perbaikan kinerja operasi dan kompetisi di industri ketenagalistrikan.

Upaya yang perlu dilakukan oleh pemerintah dalam rangka perbaikan struktur industri (butir 1) adalah menurunkan konsentrasi pasar sekaligus mengurangi entry barriers. Beberapa peraturan setingkat menteri telah diterbitkan, erakhir Permen ESDM 38/2016 tentang usaha penyediaan tenaga listrik skala kecil (UPTLSK). Melalui permen tersebut perbaikan struktur industri nasional akan terjadi, walaupun dalam skala yang lebih kecil (belum signifikan). Upaya melalui UPTLSK juga didorong oleh terbitnya Permen ESDM 10/2017 yang mengatur tentang pokok-pokok perjanjian jual beli tenaga listrik.

Upaya lanjutan untuk menurunkan konsetrasi pasar adalah seperti yang dilakukan oleh Jepang yaitu mempertahankan konsep vertically integrated namun tidak geographically integrated. Sebagai negara kepulauan tidak selayaknya bahwa natural monopoli di industri ketenagalistrikan berlaku pula dalam lingkup seluruh wilayah geografis. Pengendalian usaha ketenagalistrikan akan sangat sulit apabila hanya satu badan usaha yang mengontrol dari Sabang sampai Merauke dan dari Pulau Miangas sampai Pulau Rote. Proses desentralisasi atau pemecahan wilayah usaha menjadi opsi terkuat untuk meningkatkan layanan ketenagalistrikan. Apabila hal ini dilakukan, maka akan memberi dampak, yaitu (1) span of control 
dari badan usaha akan menjadi lebih rasional; (2) identitas lokal akan tetap dapat dipertahankan mengingat one policy fits all tidak dapat diterapkan di Indonesia; (3) proses penyebaran pembangunan yang tidak Jawa-sentris dapat lebih dipercepat mengingat listrik merupakan salah satu motor pertumbuhan industri dan kesejahteraan; dan (4) penurunan konsentrasi pasar secara signifikan di Indonesia.

Berbeda dari Jepang, konsep pemecahan (break up) yang diusulkan adalah bahwa pemegang wilayah usaha yang baru adalah badan usaha milik negara (BUMN). Konsep adaptasi ini diyakini sesuai dengan putusan Mahkamah Konstitusi atas UU 30/2009 maupun UU 21/2002 yaitu bahwa kontrol negara dan prinsip penguasaan negara atas hajat hidup orang banyak harus tetap ada. Prinsip tersebut dijaga melalui kontrol atas badan usaha milik negara (BUMN) itu sendiri. Dalam dalam praktek hukum perusahaan, upaya pemecahan wilayah usaha ini dikenal dengan istilah pemisahan. Pemisahan sendiri memliki dua kategori yaitu pemisahan murni (absolute division) dan pemisahan tidak murni (spin off).

Mengingat bahwa payung hukum untuk merestrukturisasi sistem ketenagalistrikan telah ada yaitu UU 30/2009, maka perbaikan kinerja industri ketenagalistrikan nasional harus terus diupayakan selaras dengan amanat UU tersebut. Beberapa langkah-langkah tindak lanjut yang perlu dilakukan adalah sebagai berikut.

a. Menciptakan sistem ketenagalistrikan yang tidak sentratlistik. Langkah ini dilakukan dengan meniru yang telah dilakukan oleh Jepang yaitu melalui pemekaran sistem ketenagalistrikan menjadi sistem-sistem yang lebih kecil. Setidaknya diperlukan 5 sistem ketenagalistrikan di Indonesia yaitu JawaBali-Nusra, Sumatera, Kalimantan, Sulawesi, Maluku dan Papua. Sistem-sitem tersebut diserahkan kepada BUMN hasil dari pemekaran PT PLN agar amanat konstitusi terkait larangan liberalisasi dapat terus dijaga. Dengan adanya sistem yang lebih kecil dan dikuasai oleh badan usaha yang berbeda, diharapkan span of control dari pembangunan infrastruktur ketenagalistrikan dapat ditingkatkan, bahkan dipercepat. Lebih lanjut, tariff regional dapat diterapkan dengan lebih mudah, dan peran serta daerah lebih mudah ditingkatkan. Selanjutnya konsep-konsep seperti performance based regulation (PBR) maupun tariff listrik regional dapat diterapkan karena telah ada badan usaha yang dapat diperbandingkan dalam satu sistem regulasi yang sama.

b. Pemisahan tidak murni (spin off) telah berhasil dalam industri telekomunikasi di Amerika Serikat. Pemisahan regional untuk industri ketenagalistrikan di Jepang juga telah berjalan dengan baik. Untuk itu, pemisahaan tidak murni dapat menjadi pilihan untuk meningkatkan kinerja industri ketenagalistrikan nasional.

c. Melanjutkan upaya untuk memanfaatkan bersama jaringan transmisi (dan distribusi). Regulasi yang ada saat ini terkait dengan pemanfaatan bersama atau juga disebut power wheeling perlu terus dikembangkan.

d. Membentuk institusi independen yang sebagai badan pengawas (regulator). Institusi regulator merupakan syarat lain yang perlu diadakan agar struktur, perilaku, dan kinerja dari industi ketenagalistrikan dapat berjalan dengan baik. Regulator dimaksud memiliki peran yang berbeda dari institusi pemerintah yang ada saat seperti Kementerian ESDM yang lebih banyak bergerak pada sisi kebijakan dan intervensi pendanaan. 


\section{Kesimpulan dan Rekomendasi}

Dengan memperhatikan kinerja industri ketenagalistrikan Indonesia, mempelajari literatur dan membandingkan dengan praktek negara maju, kami sampai pada rekomendasi kebijakan yang tetap sesuai dengan koridor hukum saat ini yaitu UU No. 30/2009.

1. Menciptakan sistem ketenagalistrikan yang tidak sentratlistik, dengan membentuk 5 sistem ketenagalistrikan di Indonesia yaitu Jawa-Bali-Nusra, Sumatera, Kalimantan, Sulawesi, Maluku dan Papua. Sistem-sitem tersebut diserahkan kepada BUMN hasil dari pemekaran PT PLN.

2. Melanjutkan upaya untuk memanfaatkan bersama jaringan transmisi (dan distribusi). Regulasi yang ada saat ini terkait dengan pemanfaatan bersama terus dikembangkan.

3. Membentuk Regulator Industri Ketenagalistrikan. Badan Regulasi ini dibentuk untuk menjaga agar struktur, perilaku, dan kinerja dari industi ketenagalistrikan dapat berjalan dengan baik. 


\section{Daftar Pustaka}

Joskow, Paul L. 1997. Restructuring, Competition and Regulatory Reform in the U.S. Electricity Sector. The Journal of Economic Perspectives, Vol. 11, No. 3 (Summer, 1997), pp. 119-138.

Viscusi. W. K. 2005. Economics of Regulation and Antitrust Fourth Edition. MIT Press. Cambridge (US).

Pemerintah Republik Indonesia. 2009.---. Undang-Undang Nomor 30 Tahun 2009 tentang Ketenagalistrikan. Jakarta (Indonesia).

World Energy Economic. 2015. Global Competitiveness Report 2015-2016.

Suryanto, Yusuf. 2014. Konsumsi Energi Listrik dan Pertumbuhan Ekonomi di Indonesia: Aplikasi VAR Model. Majalah Perencanaan Pembangunan. Jakarta (Indonesia).

Suryanto, Yusuf. 2015. Evolusi Struktur Industri Ketenagalistrikan Nasional. Majalah Sustaining Partnership Edisi Kelistrikan. Jakarta (Indonesia).

Nugroho, Hanan. 2004. Deregulasi Setengah Hati: Tinjauan Terhadap Restrukturisasi Sektor Energi Indonesia. Ikatan Sarjana Ekonomi Indonesia. Jakarta (Indonesia).

Nugroho, Hanan. 2012. Energi dalam Perencanaan Pembangunan. IPB Press. Bogor (Indonesia). 